\title{
NOTES
}

\section{WRAP-AROUND FINANCING: A TECHNIQUE FOR SKIRTING THE USURY LAWS?}

In recent years the inflationary spiral and the tight money market have forced interest rates to increase at an accelerated rate. As the lender is able to command a higher return on his money, he becomes increasingly aware of the limitations placed upon him by the usury laws. In the field of real property financing, lenders have employed several techniques to secure a higher rate of return while avoiding the limitations of the usury laws. Devices such as the sale-leaseback ${ }^{1}$ and sale-buyback ${ }^{2}$ have taken their place alongside contingent interest ${ }^{3}$ and "front money" loans ${ }^{4}$ as the basic trade tools of the lending institution in its efforts to construct a shield from the pitfalls created

1. A sale-leaseback involves a sale and transfer of property followed by a lease of the same property from the transferee to the transferor. Thomas, Leasebacks in Commercial and Family Transactions, 28 MONT. L. REv. 25 (1966).

THE FOLLOWING HEREINAFTER CITATIONS WILL BE USED IN THIS NOTE:

Benfield, Money, Mortgages, and Migraine, The Usury Headache, 19 CASE W. RES. L. REv. 819 (1968) [hereinafter cited as Benfield];

Hershman, Usury and "New Look" in Real Estate Financing, 4 ReAl Prop., Prob. \& Tr. J. 315 (1969) [hereinafter cited as Hershman].

2. In a sale-buyback, the investor purchases the property and immediately resells it to the former owner at the same price on a long-term installment contract. Hershman 321 .

3. The contingent interest method involves participation by the mortgagee in income from the mortgaged property above a fixed interest on the loan. It takes several forms:

percentage of gross income, percentage of gross income in excess of a specified dollar amount . . . percentage of overages, percentage of net income before taxes and depreciation or before depreciation and a percentage of a defined net income under which certain items of expense are limited for the purpose of the computation. Hershman 315.

4. The front money loan is a recently developed technique in which an investor normally contributes

up to 100 percent of the required cash investment in a project. The developer contributes his time and entrepreneurship to the undertaking. Sometimes he is the owner or has an option on the land to be developed and the deal involves sale of one-half of it to the investor for a price which gives the developer the cash needed to contribute his part to the undertaking.

The investor and the developer enter into a joint venture or partnership, or form a corporation in which the two share in the stock. The division of ownership and profits is negotiated and, in many instances, where the investor is putting up all of the cash, there is provision for the investor getting all of his money out first with an appropriate return on the investment before any split of the net income takes place. Hershman 324. 
by the usury statutes.

A new tool, the "wrap-around" loan, has recently appeared in the lender's repertory. This "new" contrivance, which has actually been in existence since the 1930 's, ${ }^{6}$ has recently become the subject of considerable interest among lenders, realtors, escrow personnel and attorneys. Although theoretically applicable to most loan transactions, the technique has primarily been utilized in real property financing, where it has been referred to variously as the "wraparound," "all-inclusive," "hold-harmless" or "overriding" mortgage or deed of trust. ${ }^{7}$

While it has been the subject of considerable legal commentary, ${ }^{8}$ the wrap-around technique has, to date, been utilized only sparingly and with a great deal of caution in the United States. ${ }^{9}$ The usury threat is undoubtedly among the reasons for the reluctance on the part of lenders to enter into wrap-around transactions, especially because the technique apparently has not yet been examined under the usury laws by an American court. ${ }^{10}$ It is the purpose of this Note to identify and resolve the issues which will arise when a wrap-around

5. For a detailed description and analysis of these techniques see P.L.I., Real Estate FinANCING: Business AND Legal Considerations (1968); Anderson, Tight-Money Real Estate Financing and the Florida Usury Statute, 24 U. Miami L. REv. 642 (1970); Hershman.

6. Healey, $A$ "New" Security Instrument, 41 J. STATE B. CALIF. 681 (1966).

7. Id. at 681 . Although there are differences in the operation and legal cffccts of the mortgage and the deed of trust when used as security devices for real property financing, these distinctions are inconsequential for purposes of the usury discussion in this Note. Consequently, the term "wrap-around mortgage" will be used hereinafter to describe the lending and security instrument applicable to wrap-around financing. Nevertheless, the principles to which this Note is addressed are equally applicable in jurisdictions which favor utilization of the trust deed, rather than the mortgage instrument, as a real property financing device.

8. See, e.g., P.L.I., supra note 5, at 1.13, 10.20-.24; Gunning, The Wrap-Around Mortgage-Friend or U.F.O., in INTERnational Council of Shopping CENTERS (REP. No. 22) (1969); A Panel on Wrap-Around Mortgages, in Proceedings of the AMERICAN Life CoNVENTION 151 (1966); Gunning \& Roegge, Contemporary Real Estate Financing Techniques: A Dialogue on Vanishing Simplicity, 3 Real Prop., ProB. \& TR. J. 325, 337-39 (1968); Healey, supra note 6; Hershman 323-24; Lowell, $A$ Current Analysis of the Usury Laws-A National View, 8 SAN Diego L. Rev. 193, 213-14 (1971); Wainberg, All-Inclusive Deed of Trust is Good Tool, Calif. Real Estate Ass'n MaG., July 1966, at 25; Healey, A Legal View of 'Wrap-Around' Mortgage, New York Law Journal, Oct. 14, 1970, at S5, col. 1.

9. Although the wrap-around is a relatively new form of instrument in the United States, it has been widely utilized in Canada where it is referred to as a "blanket mortgage." Gunning, supra note 8, at 1. 1n Canada, the lenders need not contend with the usury problem "since there are no usury laws, as such," other than a limitation against the exaction of unconscionable interest. Id. at 10.

10. See Lowell, supra note 8 , at 214 . 
loan is challenged as being usurious.

\section{The Wrap-Around Technique}

The "wrap-around" mortgage is a subsequent and subordinate mortgage secured by real property upon which there exists a first mortgage which remains outstanding and unsatisfied. The wraparound mortgage differs from a conventional second mortgage in that it entails a special agreement between the parties for payment of the first mortgage obligation by the lender, and consequently, the principal of the wrap-around loan is the sum of the outstanding indebtedness on the first mortgage and the new funds advanced. ${ }^{11}$ When the wrap-around mortgage is executed at an interest rate which exceeds the contractual rate of the first mortgage, it becomes possible for the lender to increase his effective interest yield from the overall transaction. The benefits to be derived from the use of wrap-around financing, therefore, can be realized primarily in a period of rising interest rates.

Although wrap-around financing has been employed primarily through real estate investment trusts in transactions involving large commercial loans, the technique can perhaps best be illustrated by a simplified refinancing transaction. Assume that $X$ owns Blackacre subject to a $\$ 10,000$ first mortgage bearing five percent interest with a remaining life of two years and an outstanding principal due in the amount of $\$ 5,000$ in one year and the remaining $\$ 5,000$ at maturity. Blackacre has a fair market value of $\$ 30,000$, and $X$, in order to procure additional capital, desires to refinance his real property by securing a loan on his equity. $X$ approaches $L$, requesting a loan of $\$ 10,000$ to be secured by his equity in Blackacre. Instead of consummating the loan through the issuance of a conventional $\$ 10,000$ second mortgage, $L$ offers to grant $X$ the requested loan on the condition that $X$ permit $L$ to "wrap-around" the existing first mortgage through the use of a wrap-around loan. Under this proposal, $X$ will execute and convey a new mortgage to $L$ in a face amount of $\$ 20,000$, and $L$ in return will advance the desired $\$ 10,000$ cash and agree to make payments of interest and outstanding principal under the first mortgage as they become due.

If, in the above example, the full $\$ 20,000$ principal of the wrap-

11. Gunning, supra note 8 , at 2. 
around mortgage is to be paid at the end of ten years and bear nine percent annual interest, $L$, the lender, will receive $\$ 1,800$ interest per annum. During the first year, $L$ will pay the five percent interest due under the $\$ 10,000$ first mortgage $(\$ 500)$ and will net $\$ 1,300$, an effective interest rate of thirteen percent on the $\$ 10,000$ he has advanced to $X$. At the beginning of the second year, $L$ will pay the $\$ 5,000$ principal due under the first mortgage. During the course of the second year, $L$ will receive $\$ 1,800$ interest from $X$ and will pay the five percent interest due on the remaining $\$ 5,000$ principal of the first mortgage ( $\$ 250$ ), thereby netting $\$ 1,550$ on the $\$ 15,000$ he has dispersed, an effective interest rate of 10.33 percent. At the beginning of the third year, $L$ will then pay the final $\$ 5,000$ principal due under the first mortgage, and will thereafter receive nine percent on $\$ 20,000$ for the remaining life of the wrap-around mortgage.

In the above transaction, $\mathrm{L}$, the lender, will receive an effective interest rate of thirteen percent during the first year, 10.33 percent during the second year, and nine percent, the contractual interest rate of the wrap-around mortgage, thereafter. The aggregate rate of return, or effective yield, to $L$ over the ten year maturity of the loan would, therefore, be 9.324 percent. Here, as in any typical wraparound transaction, the lender receives a higher interest return during the earlier years. The reason for this increment is twofold: (1) the lender has not advanced the full principal of the loan during the early years but nevertheless draws interest on the full amount, and (2) the lender receives the benefit of the interest differential between the low rate of the first mortgage and the high rate of the wrap-around mortgage during the remaining life of the first mortgage.

Since the return to the lender in the above example fluctuates between nine and thirteen percent, potential usury violations are present in all jurisdictions which set a statutory ceiling below thirteen percent. If the interest ceiling is below nine percent-the contractual interest rate specified on the face of the wrap-around loan-the transaction is obviously usurious. The real problems arise in those jurisdictions where maximum lawful rates fall between the nine percent contractual rate and thirteen percent, the highest annual return received by the lender. On the one hand, it could be argued that the wraparound loan is usurious whenever the statutory maximum is below the highest annual interest return to the lender (thirteen percent). On the other hand, it could be contended that, since the mortgage recites an interest rate of nine percent, the loan is usurious only when the statu- 
tory ceiling is below nine percent. Between these two extremes, it might be asserted that since the effective interest yield to the lender is 9.324 percent, the loan would be usurious in a jurisdiction which sets the permitted maximum at nine percent but non-usurious where the ceiling is ten percent.

In addition to its application in a refinancing transaction analogous to the one in the above example, the wrap-around loan can be employed in two basic types of sales transactions: (1) where a vendor wraps around his existing first mortgage obligation and finances a sale of his own real estate under a purchase money wrap-around mortgage, or (2) where a third-party lender wraps-around a vendor's prior mortgage obligation in order to finance the purchase of real property. In each of these contexts different considerations are present. As will be discussed later, a loan which would be usurious in one context may not violate the usury laws in another context.

\section{THE USURY LAWS}

The usury laws of the various states, which limit permissible interest rates in a range from seven percent in Michigan ${ }^{12}$ to twenty-one percent in Rhode Island, ${ }^{13}$ comprise a corpus of law with various exemptions and penalties. Although it is beyond the scope of this Note to present a detailed analysis of the general usury statutes, a brief sketch of their operation and effect is necessary as a preface to a discussion of the usurious or non-usurious nature of the wraparound loan.

Although receiving excessive interest for the loan of money has been disfavored for centuries, the common law did not limit the amount of interest which could be charged for a loan. ${ }^{14}$ Usury law is, therefore, predominantly a statutory creation, and several state constitutions contain usury provisions. ${ }^{15}$ The authority of the states to regulate interest rates is not dependent upon a constitutional grant but exists by virtue of the police power. ${ }^{16}$ This authority has been

12. Mich. Comp. Laws ANN. $\S 438.31$ (Supp. 1972).

13. R.I. GEN. LAwS ANN. § 6-26-2 (1970).

14. See, e.g., Yaffee v. International Co., 80 So. 2d 910 (Fla. 1955); In re Greenberg, 21 N.J. 213, 121 A.2d 520 (1956); Chrisman v. Corbin, 169 Ore. 332, 128 P.2d 959 (1942).

15. See, e.g. ARK. Const. art. 19, § 13; Cal. Const. art. 20, $\$ 22$.

16. See, e.g., IVessel v. Timberlake, 95 Ohio St. 21, 116 N.E. 43 (1916); State v. Sherman, 18 Wyo. 169, 105 P. 299 (1909). 
widely exercised; all states except Massachusetts and New Hampshire currently have a general usury law which sets a ceiling on interest rates. ${ }^{17}$

The extent to which a usury law actually regulates interest rates depends on the provisions of the specific statute which governs a transaction. State usury laws often contain exemptions relating to the character of the borrower or lender. The most common provision of this nature, which is present in the usury laws of three-fifths of the states, exempts from usury regulation all loans made to corporate borrowers. ${ }^{18} \mathrm{~A}$ number of jurisdictions also exempt banks and savings and loan associations from coverage under their usury laws, ${ }^{10}$ but these institutions are under general governmental regulation, ${ }^{20}$ and it is unlikely that they would be permitted to receive a rate of return above that provided in the state's general usury statute. ${ }^{21}$

While many jurisdictions exempt specific lenders and borrowers under the terms of their usury statutes, most states also incorporate exemptions or differential interest treatment for certain types and sizes of loans. For example, Illinois expressly exempts all business loans and loans of $\$ 5,000$ or more secured by warehouse receipts, negotiable instruments or securities; ${ }^{22}$ furthermore, Maine exempts retail sales loans. ${ }^{23}$ In regulating small loans, most states have enacted special legislation patterned after the Uniform Small Loan Law, ${ }^{24}$ which permits an interest rate above that embodied in the general usury law to be charged on loans which do not exceed a specific dollar amount. ${ }^{25}$

In the area of real property financing, interesting questions as to the validity of wrap-around loans arise in states which exempt certain first mortgages from the usury statutes or which differentiate between

17. Benfield 835 .

18. Id. at 848 .

19. See, e.g., Cal. Const. art. 20, § 22; Colo. Rev. Stat. Ann. § 73-2-10 (1964); Conn. Gen. Stat. AnN. § 37-9 (1971).

20. For example, the Federal Home Loan Bank Act sets a limit on the rate of interest which can be charged by a member of the Federal Home Loan Bank Systcm. 12 U.S.C. $\S 1425$ (1970).

21. Cf. Benfield 851 .

22. Ill. ANN. Stat. ch. 74, § 4 (Smith-Hurd I966).

23. Me. Rev. Stat. AnN. tit. 9, § 229 (Supp. 1970).

24. See Benfield 840.

25. "The original maximum loan amount under the Uniform Small Loan Act was $\$ 300.00$ and a number of States still have this limitation though other States have much higher small loan law ceilings." Benfield 840 . 
the interest rates allowed for first and second mortgages. Virginia, for example, exempts loans secured by real property whenever the transaction involves a non-agricultural first mortgage. ${ }^{26}$ North Carolina, on the other hand, provides a lower interest ceiling for certain loans secured by a first mortgage than for other types of loans. ${ }^{27}$ Under such statutory schemes, the legality of a wrap-around mortgage might depend, therefore, on its classification as a first or second mortgage. However, since the wrap-around mortgage is a subsequent and subordinate mortgage secured by real property which is already encumbered with a prior mortgage, and since the prior mortgage remains dominant and outstanding after the wrap-around loan is executed, the wrap-around mortgage has generally been considered a second mortgage ${ }^{28}$ and probably should be treated as such for usury purposes.

In addition to usury statutes affording differential interest treatment to first and second mortgages, other statutes provide beneficial treatment for real estate financing in general. Connecticut, for example, exempts most loans secured by mortgages from coverage under its usury statute. ${ }^{29} \mathrm{~A}$ number of other states permit an interest rate somewhat above that of their general usury laws to be charged upon loans secured by real property, ${ }^{30}$ and approximately one-half of the states have adopted a model statutory provision recommended by the Federal Housing Administration which exempts F.H.A. insured loans from coverage under the state's general usury statute. ${ }^{31}$

Although the existence of various exemptions insulates a portion of real estate indebtedness from coverage under the general usury statutes, the vast majority of these loans are governed by usury laws. In fact, home mortgage loans constitute the largest single area of debt subject to the general usury laws of the various states. It has been estimated that some eighty-six percent of this indebtedness is regulated by usury ceiling rates. ${ }^{32}$

26. VA. CODE ANN. § 6.1-319.1 (Supp. 1971).

27. N.C. Gen. STAT. § 24-1.1 (Supp. 1971).

28. See Gunning, supra note 8 , at 2 , where the wrap-around mortgage is characterized as a "second mortgage."

29. Conn. Gen. Stat. Ann. § 37-9 (Supp. 1971). The Connecticut exemption applies only to loans in excess of 55,000 .

30. See, e.g., Ga. Code AnN. § 57-101 (1971); Pa. Stat. ANN. tit. 41, § 3 (Supp. 1971).

31. Lowell, supra note 8, at 220.

32. Benfield 858. 
As the coverage of the usury statutes varies from state to state, so does the penalty for violations. The early usury laws were modeled after the English acts and provided that all usurious contracts were void..$^{33}$ This penalty, which dictated that both principal and interest be forfeited, was deemed too harsh in most jurisdictions and remains in only a handful of states. ${ }^{34}$ The trend has been toward mitigating the penalty to be inflicted upon the usurer. While a few states have provided that all interest and a percentage of principal shall be forfeited, ${ }^{35}$ most jurisdictions do not require any forfeiture of principal. Many of these states simply provide for interest forfeiture, either wholly ${ }^{36}$ or merely as to the illegal excess. ${ }^{37} \mathrm{~A}$ substantial number of jurisdictions have adopted a somewhat harsher penalty by providing for forfeiture of a multiple of either the interest rate ${ }^{38}$ or the excess rate. ${ }^{39}$ In addition to the civil penalties, several states have enacted criminal sanctions by making some forms of usury a felony ${ }^{40}$ or a misdemeanor. ${ }^{41}$

Although interest rates in the United States are currently governed almost exclusively by state statutes, one should not ignore the possibility of federal regulation. Recent amendments to the Economic Stabilization Act of 1970 authorize the President to "stabilize" interest rates if he deems such action appropriate. ${ }^{42}$ Moreover, a Committee on Interest and Dividends was created to assist the Cost of Living Council in the field of interest regulation..$^{43}$ Consequently, lenders should be cognizant of the fact that another period of rising interest rates might prompt the federal government to exercise its authority and supplement the state regulation of interest rates.

\section{General Evaluation of the Wrap-Around Mortgage Under THE USURY LAWS}

It is generally said that usury is divided into three necessary elements: (1) a loan or forbearance; (2) wrongful intent; (3) the exaction of usurious interest. ${ }^{44}$ The first element creates no difficulties in relation to the wrap-around loan since the transaction clearly contemplates a loan or forbearance of money. The second and third elements, however, merit examination because the presence of intent

33. See Plitt v. Kaufman, 188 Md. 606, 611, 53 A.2d 673, 675 (1947).

34. See, e.g., ConN. Gen. STAT. ANN. $\$ 37-8$ (1969) (prohibiting any legal action to rccover principal or interest); ME. Rev. Stat. ANN. tit. 9, $\$ 229$ (Supp. 1972); R.I. GEN. Laws ANN. § 6-26-4 (1970). 
and the method of computing interest are issues which are likely to arise when a wrap-around loan is challenged as usurious.

An intention to enter into a transaction in violation of the usury law is an essential element of usury. ${ }^{45}$ The requisite element is present whenever the lender intends to take or receive more than the rate of interest permitted by law. ${ }^{46}$ In most jurisdictions mutuality of intent is not essential; it is only required that the lender intended to receive a higher return than that specified in the usury statute. ${ }^{47}$ There is a split of opinion as to whether actual intent must be proved. Some courts have indicated that a corrupt intent must be shown; ${ }^{48}$ others hold that no specific or conscious intent to violate the statute is necessary and that the requisite usurious intent will be deemed present whenever the lender knowingly takes an interest rate which in fact exceeds that allowed by statute. ${ }^{49}$

35. See, e.g., VT. Stat. ANn. tit. 9, § 50(b) (Supp. 1970) (providing that the lender shall have a right to collect only one-half of the principal).

36. See, e.g., Ariz. Rev. Stat. Ann. § 44-1202 (Supp. 1971); Ga. Code ANn. § 57-112 (1971); N.J. Stat. ANN. \& 31:1-3 (1963).

37. See, e.g., Nev. Rev. Stat. § 99.050(2) (1970); Pa. Stat. ANN. tit. 41, § 4 (1954); Tenn. Code Ann. § 47-14-115 (1964).

38. See, e.g., Mont. Rev. Code Ann. \& 47-126 (1961); Tex. Rev. Civ. Stat. Ann. art. 5069-1-06 (1971); VA. CODE ANN. § 6.1-326 (Supp. 1971).

39. See, e.g., MD. ANN. CODE art. 49, § 8 (Supp. 1971).

40. See, e.g., CAL. Civ. Code § 1916-3(b) (West Supp. 1972); Мich. Comp. Laws AnN. $\S 438.41$ (Supp. 1972).

41. See, e.g., Colo. Rev. Stat. Ann. § 73-3-3(3) (1964); Conn. Gen. Stat. Ann. § 37-7 (1969).

42. Pub. L. 92-210, § 203(a)(2), 85 Stat. 743 (Dec. 22, 1971).

43. Exec. Order No. 11627, 36 Fed. Reg. 20139 (1971).

44. See Lowell, supra note 8, at 195 . Some authorities add a fourth element-an understanding that the money is to be returned. See, e.g., Anderson, supra note 5, at 645 .

45. See, e.g., Camilla Cotton Oil Co. v. Spencer Kellogg \& Sons, Inc., 257 F.2d 162 (5th Cir. 1958); East New York Sav. Bank v. Lang, 261 App. Div. 981, 26 N.Y.S.2d 21 (1941); cf. Griffin v. Kelly, 92 So. 2d 515 (Fla. 1957).

46. See, e.g., Call v. Palmer, 116 U.S. 98 (1885); Jones v. Nossaman, 114 Kan. 886, 221 P. 271 (1923).

47. See, e.g., Bowen v. Mount Vernon Sav. Bank, 105 F.2d 796 (D.C. Cir. 1939); Brooks v. Burgess, 228 Ark. 150, 306 S.W.2d 104 (1957); Rossberg v. Holesapple, 123 Utah 544, 260 P.2d 563 (1953). But see Rose v. Wheeler, 140 Cal. App. 217, 35 P.2d 220 (Dist. Ct. App. 1934); In re Bechtoldt's Estate, 159 Misc. 725, 289 N.Y.S. 838 (Sur. Ct. 1936).

48. See, e.g., Stewart v. Nangle, 103 So. $2 d 649$ (Fla. Dist. Ct. App. 1958); Shaffran v. Holness, 102 So. $2 d 35$ (Fla. Dist. Ct. App. 1958); Alvin v. Myles Realty Co., 227 N.Y. 51 , 124 N.E. 94 (1919).

49. See, e.g., Britz v. Kinsvater, 87 Ariz. 385, 351 P.2d 986 (1960); Thomas v. Hunt Mfg. Corp., 42 Cal. 2d 734, 269 P.2d 12 (1954); Loucks v. Smith, 154 Neb. 597, 48 N.W.2d 722 (1951). 
Those courts not requiring proof of actual intent have often said that whenever the contract is usurious on its face, the necessary intent will be inferred. ${ }^{50}$ The wrap-around loan, however, recites a rate of interest below that actually received by the lender and would probably not be viewed as usurious on its face. Consequently, the requisite intent must be gathered from the circumstances and operation of the loan. This should be a relatively simple task, however, since the wrap-around loan by its very nature is designed and used to secure an extra interest return beyond that specified on the face of the loan. As a result, since the requisite proof of intent is generally met by showing only that the lender knowingly endeavored to receive a return which is in fact above that permitted by law, ${ }^{51}$ there would seem to be little difficulty in establishing the existence of the necessary usurious intent where a lender knowingly executes a wraparound loan in which the effective interest yield will exceed the statutory maximum.

The third element necessary for proof of a usury violation, the exaction of usurious interest, poses more complex issues in relation to the wrap-around loan. One commentator has dismissed the usury question with regard to the wrap-around mortgage by stating that a court is "likely to hold that no usury is involved because the determination of the usury is not what the lender receives but what is charged by the lender against the borrower." 52 This is a superficial view of the transaction which assumes that the applicable usury statute regulates only the "payment" of interest and that the interest specified on the face of the wrap-around mortgage will be viewed as the controlling rate.

It is unfortunate that the usury statutes are often indiscriminately phrased in terms which prohibit the "payment" or "receipt" of interest above a specified maximum. The draftsmen probably failed to envision a loan in which the interest return received by the lender is higher than the interest rate paid by the borrower. This indiscriminate draftsmanship can be illustrated by the usury laws currently in force in California. The California constitution incorporates an interest

50. See, e.g., Jenkins v. Dugger, 96 F.2d 727 (6th Cir.), cert. denied, 305 U.S. 623 (1938); Houchard v. Berman, 79 Ariz. 381, 290 P.2d 735 (1955); MacRackan v. Bank of Columbus, 164 N.C. 24,80 S.E. 184 (1913).

51. See note 49 supra and accompanying text.

52. Hershman 324. 
limitation which provides that a lender shall not "receive from a borrower" interest above a specified rate, ${ }^{53}$ while the state's Real Estate Loan Act ${ }^{54}$ regulates the "payment of interest" in excess of a specific maximum. The situation is further confused by California's general usury statute, ${ }^{55}$ which states that the parties may contract for the "payment and receipt" of interest up to the maximum specified therein. In spite of the variances in the phraseology of these provisions, the California courts have refused to become involved in a semantic battle over whether usury is to be determined by what the borrower pays or what the lender receives. Rather, they have adopted the approach of the courts in general by looking to the substance of the transaction rather than its form in determining whether a loan is usurious. ${ }^{56}$

In addition to viewing substance rather than form, courts will examine a transaction alleged to be usurious by focusing their attention upon the rate of interest over the entire period of the obligation. ${ }^{57}$ The general rule, therefore, is that the transaction is not usurious if the return to the lender does not exceed the lawful rate over the entire period of the loan, measured from the date of execution to the date

53. CAL. Const. art. $20, \S 22$.

54. Cal. Bus. \& Prof. Code $\$ 10242$ (c) (West Supp. 1972).

55. CAL. Civ, CODE $§ 1916-1$ (West 1954).

56. See generally Glushon, The California Usury Law: The Lender's Trap and the Borrower's Windfall?, 43 J. ST. BAR of CALIF. 56 (1968); Note, California's Model Approach to Usury. 18 STAN. L. Rev. 1381 (1966). This general approach of the courts in determining whether there has been a violation of the usury laws is exemplified by the following quotation from a leading California case:

It has long been established that the courts will pierce the veil of a transaction designed as a cloak to cover the exaction of usurious interest. The substance and not the form of the transaction is controlling-the essence of the transaction rather than its trappings. Batchelor v. Mendigo, 95 Cal. App. 2d 816, 820, 213 P.2d 762, 764-65 (Dist. Ct. App. 1950).

Similar statements are contained in cases from other jurisdictions. See, e.g., Templeton v. Hickman, 278 Ala. 75, 175 So. 2d 768 (1965); Seargeant v. Smith, 63 Ariz. 466, 163 P.2d 680 (1945); Commercial Credit Plan, Inc. v. Chandler, 218 Ark. 966, 239 S.W.2d 1009 (195I); Milo Theater Corp. v. National Theater Supply, 71 Idaho 435, 233 P 2d 425 (1951); Abeloff v. Ohio Fin. Co., 313 Mich. 568, 21 N.W.2d 856 (1946); Melbo v. Rinn, 280 Minn. 72, 157 N.W.2d 842 (1968); Krim v. Morris Plan Ind. Bank, 173 Misc. 141, 17 N.Y.S.2d 472 (N.Y. Mun. Ct. 1939).

57. See, e.g., Osborne v. National Realty Management Co., 182 Ga. 892, 187 S.E. 56 (1936); Bethke v. Idaho Sav. \& Loan Ass'n, 93 Idaho 410, 462 P.2d 503 (1969); Mortgage Bond Co. v. Stephens, 181 Okla. 182, 72 P.2d 831 (1937); Pattavina v. Pignotti, 177 Neb. 217,128 N.W.2d 817 (1964). 
of maturity.$^{58}$ In the hypothetical wrap-around transaction previously set forth, the lender received an aggregate return of 9.324 percent over the entire term of the obligation. Although the annual rate of return was as high as thirteen percent, the loan would not be usurious, therefore, if an interest rate of 9.324 percent were permitted under the applicable statute.

Since the wrap-around loan gives the lender the highest return in the first few years of its operation, any prepayment by the borrower will necessarily increase the aggregate return received by the lender. Nevertheless, this will not serve to render an otherwise valid transaction usurious. It is well established that when a loan is voluntarily paid before its maturity, the contract will not be deemed usurious if the interest provided in the loan computed from the time the loan began to the absolute maturity specified in the contract is not in excess of the maximum lawful rate. ${ }^{59}$

Although a wrap-around loan may be usurious only if the aggregate rate of return, or effective yield, received by the lender over the entire period of the obligation exceeds the statutory maximum, several additional factors must be considered in evaluating the usurious or non-usurious nature of the transaction. If the illustrative wraparound loan with a nine percent contractual interest rate was consummated in a jurisdiction which permitted lenders to receive a maximum of only nine percent on an indebtedness, it would appear at first glance that under all circumstances the aggregate return would be 9.324 percent and the loan would, therefore, be usurious. When certain forms of the wrap-around mortgage are used, however, the aggregate return associated with the loan may be viewed for usury

58. Penzner v. Foster, 170 Cal. App. 2d 106, 338 P.2d 533 (Dist. Ct. App. 1959), exemplifies this general rule:

Whether a transaction is usurious is determined by the total amount of interest required to be paid under the terms of the agreement between the date of execution and the date of maturity. If the interest for the full period of the loan exceeds the maximum rate allowed, then the obligation is usurious. Id. at 109, 338 P.2d at 535 .

For similar holdings from other jurisdietions, see, e.g., Friend v. Bank of Eastman, $112 \mathrm{Ga}$. App. 756, 146 S.E.2d 110 (1965); Home Sav. \& Loan Ass'n v. Bates, 76 N.M. 660, 417 P.2d 798 (1966); Mayfield v. Oklahoma State Bank, 460 P.2d 414 (Okla. 1969).

59. See, e.g., French v. Mortgage Guar. Co., 16 Cal. 2d 26, 104 P.2d 655 (1940); B.F. Saul Co. v. West End Park N., Inc., 250 Md. 707, 246 A.2d 591 (1968); Silver Homes, Inc. v. Marx \& Bensdorf, Inc., 206 Tenn. 361, 333 S.W.2d 810 (1960). See also Annot., 75 A.L.R.2d 1265 (1961). For a discussion of the possible effect on the validity of the wrap-around loan caused by a voluntary prepayment of the first mortgage obligation by the lender, see note 68 infra and accompanying text. 
purposes as being only nine percent, the rate specified on the face of the loan. Hence there is a need for further inquiry into the different types of wrap-around loans and the usury implications of each. In the following discussion, it will be assumed that the interest rate specified on the face of the wrap-around mortgage approaches the maximum allowed by the usury statute. The validity of the wrap-around under this critical condition will then be examined in three separate real estate financing transactions: the refinancing mortgage, the basic purchase money mortgage, and the purchase money mortgage involving third party financing.

\section{The Refinancing Wrap-Around Mortgage}

When one examines the substance of a refinancing agreement which employs the wrap-around technique, violation of the usury laws becomes apparent. In the illustrative transaction previously set forth, $L$, the lender, has, in lieu of issuing a conventional second mortgage, persuaded $X$, his borrower, to give up the advantageous low-interest first mortgage as a condition to granting the loan. The fact that the borrower has been required to give up the benefits of an advantageous agreement may in itself be enough to taint the transaction as usurious. A loan which stipulates interest at the highest lawful rate may be rendered usurious when the creditor, as a condition to making the loan, requires the debtor to enter into an additional agreement with him. ${ }^{60}$ While a few jurisdictions may permit a lender to condition a loan upon the borrower's granting some collateral advantage in addition to the lawful rate of interest, ${ }^{61}$ it is universally held that contracts which give the lender a collateral benefit resulting in the exaction of usurious interest are usurious when the stipulation is made purely to evade the usury laws. ${ }^{62}$

As a general rule, therefore, any benefit or advantage exacted by the lender from the borrower, whatever its name or form, which when

60. See, e.g., In re Perry, 272 F. Supp. 73 (D. Me. 1967); Equitable Life Assur. Soc'y v. Kerpel, 38 Misc. 2d 856, 238 N.Y.S.2d 1016 (Sup. Ct. 1963); Richeson v. Wocd, 158 Va. 269, 163 S.E. 339 (1932).

61. See, e.g., Commercial Credit Plan, Inc. v. Chandler, 218 Ark. 966, 239 S.W.2d 1009 (1951); Hatridge v. Home Life \& Accident Ins. Co., 246 S.W.2d 666 (Tcx. Civ. App. 1951).

62. See, e.g., Klett v. Security Acceptance Co., 38 Cal. 2d 770, 242 P.2d 873 (1952); Virginia Hotel Co. v. Dusenberry, 218 S.C. 524, 63 S.E.2d 483 (1951). See also Ferdon v. Zarriello Bros. Inc., 87 N.J. Super. 124, 208 A.2d 186 (1965). 
added to the interest taken or received would yield a greater return than is allowed by law, renders the transaction usurious. In holding usurious a complex real estate financing scheme, the Supreme Court of Vermont in Farnsworth v. Cochran ${ }^{63}$ noted:

A contract is usurious when any premium, profit, bonus, or charge is exacted or required by the lender in excess of the money actually loaned, which, in addition to the interest stipulated, renders the return to the lender greater than the lawful rate of interest. ${ }^{84}$

When these principles are applied to a case in which real property is refinanced pursuant to a wrap-around transaction, the differential between the interest called for in the first mortgage and that specified in the wrap-around mortgage can be viewed as an exaction of additional interest and will contribute, therefore, to the aggregate interest return of the loan for usury purposes. It thus appears that even when the interest rate paid by the borrower on the face of the loan is valid, the refinancing wrap-around loan will be usurious whenever the aggregate interest return, or effective yield, to the lender computed over the entire term of the obligation exceeds the maximum interest rate embodied in the applicable usury statute.

In addition to being considered usurious because of the exaction from the borrower of an extra interest benefit through the assumption by the lender of the payment obligation under the low-interest first mortgage, the refinancing wrap-around loan with a valid contractual interest rate could have an excess effective yield due to the presence of a second element. As previously indicated, the lender derives a twofold benefit from the wrap-around transaction in that (1) he receives an additional yield from the differential in interest rates while (2) retaining the use of a portion of the interest-bearing principal of the loan during the period in which the earlier, "wrapped-around" obligation is left outstanding. This second factor is equally capable of rendering the wrap-around transaction usurious since the interest rate in any loan must be computed on the actual amount advanced from the actual date of advancement. ${ }^{65}$ The rule is set forth in

63. 125 Vt. 174,212 A.2d 818 (1965).

64. Id. at 181,212 A.2d at 824 .

65. See, e.g., American Acceptance Corp. v. Schoenthaler, 391 F.2d 64 (5th Cir.), cert. denied, 392 U.S. 928 (1968) (interest may not be charged on portions of principal not disbursed to borrower); Penziner v. West Am. Fin. Co., 133 Cal. App. 578, 24 P.2d 501 (Dist. Ct. App. 1933); Mindlin v. Davis, 74 So. 2d 789 (Fla. 1954); Barr's Adm'rx v. African M.E. Mt. Pisgah Church, 10 A. 287 (N.J. Ch. 1887). 


\section{Penziner v. West American Finance Co.:66}

In testing a transaction for usury, interest must be computed on the actual sum advanced from date of advancement . . . . While the mere fact that the whole sum loaned is not drawn promptly by the borrower does not render the loan usurious, provided the whole sum was held subject to the borrower's order, yet when such a result is in accordance with an agreement made at the time of the loan, the transaction is obviously usurious". . . . If the agreement contemplates that the entire loan shall be available to the borrower, mere delay in its payment to him, in the absence of intent to evade the Usury Law, does not make the loan usurious, but if, as a condition of the loan, the borrower is required to leave part with the lender, interest in excess of the legal rate on [the] sum actually advanced is usurious. ${ }^{67}$

Applying this rule to the hypothetical refinancing transaction, it can be observed that during the first year $L$, the lender, will receive interest on the full $\$ 20,000$ at a time in which he has advanced only $\$ 10,000$. Furthermore, $L$ will not actually disburse the full $\$ 20,000$ until two years following the execution of the wrap-around mortgage when the principal amount remaining under the first trust deed becomes due. Hence the wrap-around lender in the early stages of the loan period has advanced a sum less than the full principal on which he is drawing interest. Since the interest return must be calculated on the basis of the principal actually advanced, the net effect of the above delay in advancement of principal will be an increase in the aggregate interest return of the loan. When the face interest rate of the wrap-around refinancing loan is already at or near the statutory maximum, the aggregate interest return, therefore, will undoubtedly be usurious. ${ }^{68}$

The fact that a mortgage corporation had collected interest on funds which it had not actually advanced was determinative to a

66. 133 Cal. App. 578, 24 P.2d 501 (Dist. Ct. App. 1933).

67. Id. at 590,24 P.2d at 506 .

68. The refinancing wrap-around loan with a face interest rate at the statutory maximum would probably be considered usurious even under the unlikely circumstance that a lender voluntarily and promptly prepays the attractive first mortgage obligation despite his contractual right to make payments only as they become due. Whether or not such a voluntary prepayment would be a valid defense to a usury charge would depend, first of all, on whether a court will look at the course of performance of the loan contract in determining its validity, or will look exclusively at the contract as it was made. However, even if a court were willing to accept the former approach and consider that for usury purposes the full amount of the loan principal had in fact been advanced, the lender would still be confronted with the fact that the low-interest benefit of the first mortgage had been exacted from the borrower as a condition or integral part of the wrap-around loan. Hence the wrap-around loan would still be usurious because of the presence of this second element. See notes 60-64 supra and accompanying text. 
holding by the Florida Supreme Court in Mindlin v. Davis ${ }^{69}$ that a certain refinancing transaction analogous to a wrap-around loan was usurious. In this case the maximum lawful interest rate in Florida was ten percent, and a mortgage corporation had persuaded certain borrowers to apply for a ten percent mortgage loan in the principal amount of $\$ 3,300$ for the purpose of consolidating borrower's various prior obligations, including an existing five percent first mortgage on their home. The mortgage corporation then sold the $\$ 3,300$ mortgage to other lenders and informed the borrowers that the loan would be closed directly with the assignee lenders as mortgagees. Implicit in the terms of the application and the negotiations for this mortgage was an agreement that the first mortgage should be discharged out of the proceeds of the new mortgage. The lenders paid the cash portion of the principal to the borrowers and retained the remaining principal to be applied in payment and discharge of the first mortgage. In lieu of immediately discharging the first mortgage pursuant to the implied understanding among the parties, however, the lenders merely paid the monthly installments thereon in the name of the borrowers as they became due.

The borrowers then brought an action for forfeiture of interest as provided under the Florida usury statute ${ }^{70}$ alleging that the note and mortgage were usurious. Although the loan recited an interest rate of ten percent, the maximum lawful rate, the Florida Supreme Court held that retention by lenders of part of the loan principal without a corresponding abatement of interest constituted a scheme designed to exact excess interest over that provided in the note and, therefore, rendered the whole transaction usurious. ${ }^{71}$ The court noted:

Since time as well as amount of principal is a factor in the calculation of interest, it is evident that retention of a substantial portion of the loan without a corresponding abatement of interest on the amount retained has the effect of substantially increasing the per centum of interest on the actual amount advanced by the lenders and received by the borrowers, which is the significant amount contemplated by the statute. It is undisputed in the evidence that the retention by the lenders of that portion of the principal earmarked for the [first] mortgage was by their original intention and design ..... It is not difficult to appreciate the effect of such a scheme and to recognize it as a device or contrivance for the exaction of usurious interest condemned by the statute. ${ }^{72}$

69. 74 So. $2 \mathrm{~d} 789$ (Fla. 1954).

70. Fla. Stat. ANN. § 687.03 (Supp. 1972).

71. 74 So. $2 d$ at 793.

72. Id. 
Although there apparently are no reported decisions which have dealt with the usury issue in a wrap-around transaction, ${ }^{73}$ the Florida Supreme Court in Mindlin held usurious a loan which, in effect, gave the lender the same dual advantages which he would have received had the transaction been consummated by employing a wrap-around mortgage. It should be noted, however, that the loan which was held usurious, while having the same effects as a wrap-around transaction, did not have the additional element of an exaction of an advantageous first mortgage as a condition to the granting of the loan. The lenders in Mindlin rctained the benefit of the low-interest first mortgage not as a condition, or requirement, of the second loan, but rather as a unilatcral action in violation of an implied understanding that the prior loan be extinguished immediately.

On the basis of the foregoing discussion, it would appear that a wrap-around refinancing agreement with a valid contractual interest rate would be usurious if the loan renders an effective interest yield in excess of the statutory ceiling due to the existe. 1 ce of either, or both, of two factors: (1) the lender receives interest on a full loan principal which exceeds the total funds he has actually advanced ${ }^{74}$ or (2) the lender exacts additional interest in the form of reaping the bcnefits of the low intercst rate in the prior obligation which is "wrapped around."

\section{The Purchase Money Wrap-Around Mortgage}

The legal consequences of wrap-around financing vary when viewed in the context of a sales transaction. This can be illustrated by altering the facts of the example previously used as follows: $X$ owns Blackacre, real property valued at $\$ 30,000$, subject to an outstanding $\$ 10,000$ first mortgage bearing five percent interest, with $\$ 5,000$ of the principal due in one year and the remaining $\$ 5,000$ principal due in two years. $P$ desires to purchase Blackacre, but offers only $\$ 10,000$ as a down payment. $X$ agrees to sell the real property to $P$ under the following terms: $P$ will make the $\$ 10,000$ down payment to $X$ and will execute a wrap-around mortgage for $\$ 20,000$ bearing nine percent interest, naming $X$ as the mortgagee thereunder. $X$ in return will convey the property to $P$ and will covenant to con-

73. See note 10 supra and accompanying text.

74. See notes 65-72 supra and accompanying text.

75. See notes 60-64 supra and accompanying text. 
tinue discharging the remaining obligations under the outstanding first mortgage as they mature.

When viewed in the above context of a sales transaction, the wrap-around loan differs from the refinancing loan in two basic ways which diminish the usury implications of the overall transaction. First, in the purchase money loan, unlike the refinancing loan, the lender does not exact from the borrower the interest benefit of an advantageous contract. Whereas the benefits of a low interest first mortgage are transferred from borrower to lender as an integral part of the refinancing loan, the wrap-around lender in the sales transaction merely remains personally liable under a prior obligation $^{i 6}$ for which the purchaser-borrower was never personally obligated. A second difference between the two types of wrap-around loans lies in the extent to which the lender actually advances the full principal of the loan upon which he is drawing interest. In the hypothetical refinancing transaction, the borrower becomes obligated under a $\$ 20,000$ wrap-around mortgage and in exchange receives $\$ 10,000$ cash plus the lender's promise to pay the borrower's outstanding $\$ 10,000$ debt obligation on the first mortgage. During the early stages of the loan period before the first mortgage is satisfied, the lender receives interest on the full $\$ 20,000$ principal; but, he has actually advanced only $\$ 10,000$ of that amount. On the other hand, the purchaser-borrower in the sales transaction appears to receive a loan for the full $\$ 20,000$ because he has purchased property valued at $\$ 30,000$ for a down payment of $\$ 10,000$, and because the $\$ 10,000$ first mortgage, although theoretically encumbering the purchased property, is the personal obligation of the seller-lender.

At first glance, therefore, the two elements which tainted the effective interest yield in the refinancing wrap-around loan-the exaction of an extra interest benefit and the retention of part of the interest-bearing principal ${ }^{77}$-appear to be absent from the basic purchase money wrap-around loan. Yet, although the purchaser is paying only nine percent on the amount of his indebtedness in the above illustration, the overall profit to the seller-lender from the entire transaction, due to the fact that the lender possesses the low-interest

76. Since a person may loan or sell his credit without violating the usury laws, the extra return to the lender under the purchase money wrap-around mortgage may be viewed as nonusurious compensation for his loan of credit. See generally Annot., 104 A.L.R. 245 (1936).

77. See text accompanying notes 74-75 supra. 
first mortgage obligation, is 9.324 percent. If the lawful interest maximum were set at nine percent, the same as the contractual rate of the loan, any refinancing wrap-around loan showing the above performance figure would be usurious. However, a distinction must be drawn in the case of the purchase money wrap-around mortgage in that the seller-lender has not agreed to pay the debts of another, but has continued to be responsible for a debt under which he was always personally obligated. In essence, what might otherwise appear to be an extra intcrest return exacted by the lender as an integral part of the purchase money wrap-around loan is actually only an independent profit resulting from the fact that the lender is merely re-lending at a high interest rate a sum of money which he has personally borrowed at a lower rate. If one borrows a sum of money, the fact that the lender himself had previously borrowed the principal amount at a lower rate gives the borrower no cause to complain. ${ }^{78}$ Consequently, the fact that the seller-lender in the purchase money wraparound transaction has procured a portion of the principal amount which he is lending to the purchaser at an interest rate below that which he has charged to the purchaser-borrower should not permit the latter to successfully challenge the loan as usurious. In fact, it is the use of this "leverage" which enables most institutional lenders to operate at a profit.

It follows, then, that the interest differential, or "leverage," inherent in the purchase money wrap-around loan is an independent profit, and there is no "exaction" of interest element which can give rise to an excess effective yield for usury purposes. The purchase money wrap-around transaction can be attacked, therefore, only on the remaining ground that the vendor is receiving interest on a principal amount which is greater than that which he has actually advanced. This attack will probably fail because the seller-lender continues to be the sole obligor under the first mortgage obligation, which, when added to the lender's remaining cquity in the property, will be equal to the full principal of the wrap-around loan.

The problem of determining the amount which should be treated as the principal in computing the allowable rate of interest in a loan was recognizcd by the California District Court of Appeals in Orlando v. Berns. ${ }^{79}$ In this case, a borrower had fallen deeply in debt,

78. Cf. note 82 infra and accompanying text.

79. 154 Cal. App. 2d 753, 316 P.2d 705 (Dist. Ct. App. 1957). 
had encountered difficulty in obtaining a loan to liquidate his debts, and was in imminent danger of losing his property. As a result of negotiations, certain lenders promised to liquidate borrower's outstanding indebtedness, in exchange for which the borrower conveyed his real property to the lenders and received back a written option to repurchase. In order to extinguish the borrower's prior debts, the lenders, in turn, obtained an independent loan of $\$ 145,000$ upon a substantial portion of the property, evidenced by their own promissory note and secured by a deed of trust on the property. The lenders then used the $\$ 145,000$ proceeds of their independent loan and an additional sum of $\$ 30,874.20$ cash to pay the borrower's prior debts as agreed. The lenders agreed to pay the monthly installments of principal and interest on the $\$ 145,000$ loan until the borrower exercised his option, at which time the borrower would buy the property back subject to the outstanding indebtedness of this loan. Thereafter, the borrower exercised his option to repurchase at the agreed price of $\$ 200,000$ less the amount of the principal balance remaining due on the $\$ 145,000$ loan. ${ }^{80}$

The borrower subsequently brought an action alleging that the agreement constituted a usurious loan. The trial court found, first of all, that the transaction was in fact a loan to the borrower and not a sale with an option to repurchase. The trial court then held the loan to be usurious by calculating the interest rate based on a principal of only $\$ 30,874.20$, the amount of cash advanced by the lenders towards liquidating the borrower's debts. ${ }^{81}$ On appeal, however, the California District Court of Appeals concluded that the loan was not usurious and held that the principal of the loan should include not only the amount the lenders had advanced in cash, but the $\$ 145,000$ which they had borrowed independently on their own promissory note and used toward extinguishing the borrower's original indebtedness. As stated by the Orlando court:

The $\$ 145,000$ was an integral part of the transaction. The defendants [lenders] hired it from the insurance company upon their own promissory note as makers. The fact that some of plaintiff's [borrower's] property was used as

80. Id. at 754,316 P. $2 \mathrm{~d}$ at 706.

81 . By deducting the $\$ 30,874.20$ from $\$ 60,509.20$, the repurchase price of $\$ 200,000$ ininus the unpaid residue of the $\$ 145,000$ loan at the time the repurchase option was exercised, the lower court held that the lenders had exacted $\$ 29,635$ from the borrower. "The latter sum, treated as interest upon $\$ 30,874.20$ obviously exceeded . . . the maximum rate allowable under the California usury laws." Id. at 758,316 P.2d at 708 . 
security does not detract from the fact that defendants obtained the money (which plaintiff was unable to do) and made it available to liquidate his debts and refinance his undertaking. Defendants continued as obligors to the insurance company and will continue so until plaintiff completes his repurchase and assumes the payment of the unpaid balance of $\$ 145,000$. Indeed, they will continue obligated until the entire amount is paid unless and until the insurance company lender accepts the plaintiff as sole debtor in lieu of the defendants. ${ }^{\mathrm{k2}}$

In holding that the amount borrowed independently by the lenders in order to pay off their borrower's prior indebtedness, even though their borrower's property was used as security for the loan, should be considered as principal in determining whether the usury laws had been violated, the court in Orlando recognized that a loan could be predicated upon funds obtained through exercise of a lender's credit. Pursuant to this principle, it would seem that the amount loaned to the purchaser of property by a vendor who has wrapped around a prior loan obligation obtained by him on his own credit should be computed in the same fashion, thus permitting the vendor to charge the maximum statutory interest rate on the full principal amount of the wrap-around loan without incurring an excess effective yield for usury purposes. ${ }^{83}$

The legitimacy of the wrap-around loan in a sale of real property is further enhanced by the fact that where there is a bona fide sales transaction, the seller may designate a lower cash price and a higher term price without violating the usury laws. ${ }^{84}$ If the vendor is free to set a higher price for a credit sale, he should also be able to condition a credit sale upon retention of the benefits of his first mortgage by insisting that the wrap-around technique be employed.

82. Id.

83. It should be noted, however, tbat the refinancing transaction which was deemed nonusurious in Orlando is distinguishable from the refinancing wrap-around technique deemed usurious in the previous section of this Note. Contrary to the typical wrap-around refinancing loan, tbe deed of trust in Orlando was procured by the lenders on tbeir own credit so as to make them personally obligated tbereunder, and there existed no prior advantageous loan to be "exacted" from the borrower.

84. See, e.g., Mid-State Homes, Inc. v. Staines, 161 So. 2d 569 (Fla. Dist. Ct. App. 1964); Plastics Dev. Corp. v. Flexible Prods. Co., 112 Ga. App. 460, 145 S.E.2d 655 (1965); Falcone v. Palmer Ford, Inc., 242 Md. 487, 219 A.2d 808 (1966); Aglio v. Carousel, Inc., 34 Misc. 2d 79, 228 N.Y.S.2d 350 (Sup. Ct. 1962); Lamb v. Ed Maher, Inc., 368 S.W.2d 255 (Tex. Civ. App. 1963). See also Annot., 14 A.L.R.3d 1065 (1967). The existence of the "time price differential" exception prompted the New York Court of Appeals to declare that the purchase money mortgage was not a "loan" which could be governed by the New York usury statute. See Mandelino v. Fribourg, 23 N.Y.2d 145, 242 N.E.2d 823, 295 N.Y.S.2d 654 (1968). 
It would appear, therefore, that when a vendor of real property wraps around his prior Ioan obligation in order to finance a sale of his own property and imposes the maximum statutory interest rate on the face of the resultant purchase money wrap-around mortgage, the usury laws have not been violated. The dual elements which taint wrap-around Ioans in the refinancing context-(1) the exaction from the borrower of his prior advantageous Ioan and (2) the fact that the lender has advanced less than the principal amount of the wraparound mortgage-are not present in a sales transaction where the vendor extends a purchase money wrap-around loan to his purchaser.

\section{The Purchase Money Wrap-Around Mortgage with Third PARTY FINANCING}

The wrap-around loan must be viewed in still another context which incorporates some of the elements of the refinancing and sales transactions described above. The wrap-around loan could conceivably be employed in a case where a vendor and purchaser look to a third person for aid in financing the purchase of real property. The transaction in this context may be illustrated as follows: $X$ owns Blackacre, real property valued at $\$ 30,000$, subject to a $\$ 10,000$ first mortgage which bears five percent interest and will mature in two years. $P$ desires to purchase Blackacre, but only offers $\$ 10,000$ as a down payment. $X$ and $P$ approach $L$ to secure financing of the sale. $L$ agrees to finance the transaction if $P$ will execute and convey to $L$ a wrap-around mortgage bearing nine percent interest on a principal amount of $\$ 20,000$ and if $X$ agrees to permit $L$ to assume the obligations under the outstanding first mortgage. If the agreement is consummated, $P$ will receive title to Blackacre, pay the $\$ 10,000$ down payment to $X$ and pay to $L$ the amounts which become due under the $\$ 20,000$ wrap-around mortgage. $L$ in return will pay $X \$ 10,000$ cash, representing $X$ 's remaining equity in Blackacre, and will pay the obligations under the first mortgage as they mature.

As previously discussed, the wrap-around loan will be usurious whenever the effective interest yield to the lender exceeds the lawful maximum. When the interest specified on the face of the wrap-around mortgage is within the statutory ceiling, the effective yield will nevertheless be excessive and the loan will, therefore, be usurious if the lender's return is enhanced through the presence of either of two elements: (1) the receipt of interest on a principal amount in excess of that which the lender has advanced or borrowed on his own credit; 
or (2) the receipt of an interest differential between the high rate of the wrap-around loan and the low rate embodied in a prior obligation which is exacted by the lender as a condition to granting the loan.85

In the above example, if $L$, as lender under this "tripartite" purchase money wrap-around mortgage, merely covenants to pay the obligations under the first mortgage as they become due, he will be receiving interest on an amount above that which he has advanced or borrowed on his own credit; hence, the first element of the above test will be present. Whenever the contractual interest rate is near the statutory ceiling, therefore, the aggregate return to $L$ will exceed the lawful maximum, and the transaction will be usurious. Following the rule that interest must be computed on the actual sum advanced from the date of advancement, it appears that the fact that the lender is collecting interest on funds which he has not actually advanced would taint the transaction with usury pursuant to the Mindlin holding discussed previously. ${ }^{86}$

If the lender, however, rather than merely covenanting to pay the obligations under the first mortgage, could validly assume the prior mortgage, he might under some circumstances be deemed to have advanced, in cash or borrowed funds, the full principal amount of the wrap-around loan. Under such circumstances the tripartite wraparound sales transaction with a contractual interest rate at the maximum statutory level might not be usurious. The propriety of including as principal in one loan funds which were independently borrowed by the lender in another loan, even when the lender has pledged the borrower's property as security thereon, was established in the Orlando case. ${ }^{87}$ It should be noted, however, that an assumption of a first mortgage does not ordinarily release the original mortgagor from his obligations thereunder, but merely makes him a surety for the assuming party who becomes the principal obligor. ${ }^{88}$ This fact may serve to distinguish and invalidate the tripartite loan of borrowed funds from the basic purchase money wrap-around mortgage and the analogous loan transaction upheld in Orlando. By emphasizing the fact that the Orlando lenders had obtained and made available

85. See notes 60-64, 65-72 supra and accompanying text.

86. See notes 65-67, 69-72 supra and accompanying text.

87. See note 82 supra and accompanying text.

88. See, e.g., Layton v. West, 271 Cal. App. 2d 508, 76 Cal. Rptr. 507 (Dist. Ct. App. 1969); Betts v. Brown, 219 Ga. 782, 136 S.E.2d 365 (1964); Smith v. General Inv., Inc., 246 Miss. 765 , 150 So. $2 \mathrm{~d} 862$ (1963). See also G. OsBorne, HANDBooK on the LAW OF MORTGAGES $\$ 247$ (2d ed. 1970). 
funds "upon their own promissory notes as makers," 89 the court in Orlando was perhaps inferring that only those funds obtained by a party as sole obligor in one loan could be made the proper subject of the principal extended by the same party as a lender in another loan.

Of course, the mortgagee of the first mortgage could expressly agree to accept the assuming wrap-around lender as his sole debtor and release the vendor of the encumbered property from all liability for the debt. ${ }^{90}$ If this were the case, a stronger argument could be made for including the amount remaining due on the prior loan as principal of the wrap-around loan, since the wrap-around lender would be the sole obligor under the first mortgage and, therefore, would fall more closely within the factual situation declared nonusurious in Orlando. ${ }^{91}$

Even if the lender could establish that he has in fact made a bona fide loan of funds borrowed on his credit, the tripartite purchase money wrap-around transaction might still be deemed usurious if the benefits of the first mortgage were viewed as additional interest exacted as a condition of granting the loan. ${ }^{92}$ Of course, the difference here from the simple refinancing transaction discussed earlier is that the benefits of the prior obligation could not be exacted from the borrower in the tripartite transaction because he never had any claim or right to them. Rather, the low-interest obligation under the first mortgage has been held by the vendor, who is not a borrower in the tripartite purchase money wrap-around transaction and is essentially, therefore, a stranger to the basic debtor-creditor relationship of that loan. To pursue this line of attack, then, one would have to argue that

89. 154 Cal. App. 758, 316 P.2d at 708. See note 82 supra and accompanying text.

90. See, e.g., Seale v. Berryman, 46 Ariz. 233, 49 P.2d 997 (1935); Chatterley v. Safe Deposit \& Trust Co., 168 Md. 656, 178 A. 854 (1935); State ex rel. Comm'rs of the Land Office v. Pitts, 197 Okla. 644, 173 P.2d 923 (1946). See also G. Osborne, HandBooK on the LAW OF MORTGAGES $\S 247$ (2d ed. 1970).

91. A similar argument could be made by the wrap-around lender in the refinancing wraparound transaction discussed previously. However, in the unlikely event that the lender in the refinancing loan was able to assume the prior loan and secure a release of the original obligor thereon, and then persuade a court that he has in fact advanced the full principal amount in cash or funds borrowed on his own credit, the validity of the wrap-around loan would by no means be established because the second usurious element in the refinancing loan would still be present. Specifically, the fact that the lender has exacted from the borrower the benefits derived through the interest differential between the first and wrap-around mortgages would in itself be sufficient to taint the transaction as usurious. See notes 60-64 supra and accompany. ing text.

92. See notes 60-64 supra and accompanying text. 
since the vendor was forced to permit the lender to assume the advantageous first mortgage as a condition to financing the sales transaction, even though the vendor is essentially a third party to the basic wrap-around loan, the benefits derived therefrom should still be deemed additional interest which renders the transaction usurious. However, since nothing is exacted from the borrower, and since the bonus derived from the assumption of the first mortgage is given, rather, by the vendor for his own purpose to induce the making of the loan, a court would probably reject the above argument. Such a court would then hold that the exaction of the beneficial loan from the vendor in the tripartite sales transaction is not to be viewed as additional interest capable of inflating the effective yield of the loan for usury purposes. This would be in accord with numerous decisions which have held that a bonus given or paid to a lender by a third party, for his own purpose or reasons, to induce the making of a loan, does not taint the transaction as usurious. ${ }^{93}$

Evaluation of the usurious or non-usurious nature of the wraparound loan in this tripartite context is not as clear cut as it was in the two-party refinancing and purchase money transactions. While it can safely be assumed that no exaction of extra interest from the borrower is present, it appears that the lender is receiving interest on a principal amount which is greater than that which he has advanced. If the lender merely covenants to make payments on the prior loan or simply assumes that obligation, a transaction with a contractual interest rate at or near the statutory maximum would probably be usurious because the lender has not actually borrowed the amount of the prior loan as sole obligor thereunder. The difficult case is where there has been a total assumption by a lender of the prior indebtedness which completely releases the original mortgagor. Here, a strong argument could be made for including the amount of the prior obligation as principal advanced by the lender since he has assumed sole liability for the prior indebtedness. If this theory were accepted by the courts, the loan with a contractual interest rate at the statutory maximum would not be usurious. However, it is perhaps more likely that a court would hold that borrowed funds can be viewed as principal only when the initial loan was procured by the lender on his own

93. See, e.g., Fred G. Clark Co. v. E.C. Warner Co., 188 Minn. 277, 247 N.W. 225 (1933); Goodman v. Seely, 243 S.W.2d 858 (Tex. Civ. App. 1951); Greenberg v. Manganese Prods., Inc., 39 Wash. 2d 79, 238 P.2d 1194 (1951). 
credit and not through coerced assumption of an outstanding loan. If the latter viewpoint were adopted, the transaction would be usurious.

In conclusion, the tripartite sales financing transaction employing the wrap-around technique would probably be deemed usurious whenever the Iender charges an interest rate at or near the statutory maximum because the additional factors of delayed principal advancement and interest benefit exaction would probably be deemed to inflate the effective interest yield in excess of the statutory limit. However, the Iender's chances of eliminating the effect of these factors for usury purposes and of successfully defending a usury charge are greatest in cases where the lender assumes exclusive liability for the first mortgage and, contemporaneously, procures the release of the original obligor from any obligation thereunder.

\section{CONCLUSION}

The prudent lender will investigate the potential effects of the usury laws before entering into a loan employing the wrap-around technique. The first inquiry should focus on the applicable statute to determine whether the contemplated loan is exempted from coverage. If the usury law does govern the transaction, the interest return of the loan must be tested for usury by computing the interest over the entire period of the loan. Consequently, any wrap-around transaction will be non-usurious if the effective yield to the lender computed over the entire period of the obligation does not exceed the maximum interest rate permitted by statute.

Where the wrap-around borrower is paying an interest rate at or near the statutory maximum, a refinancing transaction employing the wrap-around technique will produce an effective yield to the lender in excess of this lawful limit and will, therefore, be usurious. This is because the Iender is receiving interest on a greater amount than he has advanced and because the exaction of the advantageous prior obligation from the borrower as a condition to granting the refinancing loan will be viewed as additional interest. In a sales transaction, on the other hand, a vendor may wrap-around his prior obligation, charge a contractual interest rate which is at or near the statutory ceiling, and receive an overall profit from the entire transaction in excess of the statutory maximum without violating the usury laws. Such a basic purchase money wrap-around is not usurious because there is no element of exaction when the vendor wraps around his 
personal debt and because the seller-lender has actually advanced equity and borrowed funds equal to the full principal of the loan. Finally, when a third party finances a sales transaction by wrapping around an existing obligation, charges a contractual interest rate at or near the statutory ceiling, and thereby receives an overall profit in excess of the statutory maximum, the loan is usurious if the lender has not assumed the prior obligation in such a manner as to become the sole obligor thereunder. Even if there was such an exclusive assumption, the transaction might still be deemed usurious because the bona fides of the loan of borrowed funds in this context are questionable.

As a result of these conclusions, the wrap-around lender participating in refinancing or tripartite loans should charge a contractual interest rate sufficiently below the statutory ceiling to limit his effective interest yield over the entire term of the loan to the statutory maximum and thereby ensure the legality of the transaction. The wrap-around loan may prove most beneficial to lenders in the form of the purchase money loan, where the seller-lender should be able to charge the statutory maximum to his borrower and receive an overall profit in excess of the lawful rate without violating the usury laws.

It must be recognized that the complex usury issues discussed in this Note have yet to meet judicial scrutiny. ${ }^{94}$ This Note has attempted to speculate as to the probable judicial resolution of such issues by examining traditional usury principles and previous judicial treatment of analogous financing schemes. If lenders are able to understand the impact of the usury laws upon the wrap-around loan, they should have no fear of entering into transactions employing the wrap-around technique. However, lenders should be aware that the wrap-around loan may also require special treatment in relation to several other factors such as the application of "first lien" requirements for certain institutional lenders, ${ }^{95}$ Securities Exchange Commission and Blue Sky Law disclosure requirements for corporate lenders, and problems created by the presence of acceleration clauses in pre-existing loan obligations. ${ }^{96}$ In spite of the precautions which must be taken prior to its use, the wrap-around loan should prove to be of great value to the lender who utilizes the technique judiciously.

94. See note 10 supra and accompanying text.

95. See generally P.L.I., supra note 5.

96. See generally Healey, supra note 6. 


\section{,}

